\title{
INTERNALISASI NILAI-NILAI TOLERANSI INTRAUMAT BERAGAMA PADA PENGGUNAAN E-BOOK الموسوعة الفقهية الكويتية)/ENSIKLOPEDI HUKUM ISLAM KUWAIT) DI PESANTREN MAHASISWA DARUL ULUM AL-FADHALI MERJOSARI MALANG
}

(Studi Kasus Pemanfaatan E-Book Sebagai Media Pembelajaran Untuk Internalisasi Nilai-nilai Toleransi Intraumat dan Antarumat Beragama di Pesantren Mahasiswa Darul Ulum Al-Fadhali Merjosari Malang)

\author{
Abdul Wahid ${ }^{1}$, Mawan Kriswantono ${ }^{2}$ \\ Teknik Informatika, Institut Teknologi Nasional Malang \\ wahidfilosof@gmail.com
}

\begin{abstract}
ABSTRAK
Artikel ini membahas hasil penelitian tentang pemanfaatan media e-book Al-Mausuat Al-Fiqhiyyah AlKuwaitiyyah (الموسوعة المفقية الكويتية) sebagai media pembelajaran untuk efektifitas internalisasi nilai-nilai toleransi intraumat dan antarumat beragama di Pondok Pesantren Mahasiswa Darul Ulum Al-Fadhali Merjosari Kota Malang. Hardcopy kitab ensiklopedia ini berjumlah 45 Jilid. Lalu disebarkan dalam bentuk digital. Sedangkan $e$ book ini berupa pengembangan format digital yang mulanya pada awal tahun 2000-an disebarkan dalam bentuk CD-R atau CD-RW. E-book ini memuat referensi kitab-kitab klasik yang ditulis mulai abad III-XH. Ensiklopedia fiqih terbitan Departemen Wakaf dan Urusan Islam Kuwait ini mempunyai beberapa kelebihan yang tidak dimiliki $e$-book lain yang sejenis. Diantara keunggulan kitab $e$-book ini penyusunannya tidak berdasarkan mazhab tertentu, tetapi semua mazhab fiqih Islam yang ada dijelaskan satu persatu lengkap dengan dalil Al-Quran, hadits, ijma', dan qiyas, tanpa menampilkan kecenderungan pada madzhab hukum Islam tertentu. Sehingga aplikasi $e$-book ini sangat efektif untuk internalisasi nilai-nilai inklusifisme pemikiran hukum Islam dan tidak fanatik membabi buta. Memegang teguh apa yang diyakini, tanpa menyalahkan hasil pemahaman kelompok lain.
\end{abstract}

\section{Keyword : Internalisasi, Toleransi, Al-Mausuat Al-Fiqhiyyah, Pesantren, Hukum Islam}

\section{PENDAHULUAN}

Diantara perkembangan model lembaga pendidikan Islam adalah pesantren mahasiswa. Yaitu sebagai alternatif bagi para mahasiswa untuk menimba ilmu pengetahuan di perguruan tinggi sekaligus nyantri menambah ilmu pengetahuan agama Islam. Hampir di sekitar wilayah perguruan tinggi Indonesia terdapat asrama-asrama dan pesantren yang memberi layanan pendidikan agama seperti pesantren hafalan Al-Quran, pengajaran kitab-kitab Islam klasik, dan lain sebagainya, temasuk kampus-kampus di kota Malang.

Pondok Pesantren Darul Ulum Al-Fadhali Merjosari Kota Malang, adalah bagian pesantren mahasiswa yang berkhidmah untuk memberi bimbingan ilmu-ilmu kepesantrenan. Dari sisi kurikulum, pesantren ini hampir tidak ada bedanya dengan pesantren-pesantren salaf yang lain, yang khusus mendalami ilmu agama. Kemiripan ini tak lepas dari background sang pendiri (alm. K.H. Muhammad Rofi' Mahmud) yang asli alumni pesantren salaf (tradisional).

Sebagaimana yang dimaklumi, pesantren merupakan lembaga pendidikan Islam Indonesia yang sampai saat ini masih survive dengan segala dinamikannya. Kini hampir seluruh pesantren telah berkembang pesat dari berbagai aspeknya. Di antara perkembangannya adanya beragam unit pendidikan seperti unit pengajian kitab-kitab salaf yang akrab disebut dengan kitab kuning, madrasah diniyah (sekolah agama kurikulum lokal). Kurikulum khas pesantren tradisional di Indonesia yang hampir bisa dipastikan adalah bahan ajar 'kitab kuning' (istilah buku klasik yang dicetak dengan kertas warna kuning).

Pondok pesantren Darul Ulum Al-Fadhali adalah pesantren yang mewarisi tradisi pesantren salaf, namun tetap beradaptasi dengan perkembangan teknologi informasi dengan tetap tidak mengurangi nilai-nilai klasiknya. Dari sisi media, model, dan metode, pembelajaran di pesantren sampai saat ini masih seperti 100an tahun yang silam. Metode yang paling popupar sampai saat ini adalah metode bandongan. Yaitu metode transfer keilmuan atau proses belajar mengajar di mana sang kiai membacakan, menerjemah, dan menerangkannya. Sedangkan, santri atau murid hanya mendengarkan, dan mencatat terjemahan atau keterangan dari kiai.

Keberadaan kurikulum pesantren-pesantren di Indonesia hampir bisa dipastikan mempunyai mengajarkan ilmu Al-Quran, hadits, akidah, fiqih, tasawwuf, nahwu, sharraf, dan ilmu-ilmu alat yang lain. Adapun buku-buku ajar di pesantren pada umumnya masih menggunakan buku cetak warna kuning atau lebih akrab dikenal dengan istilah "kitab kuning”. Seiring dengan perkembangan teknologi dan media informasi, khususnya 10 tahun terakhir ini, hampir semua pesantren berevolusi dari berbagai bidangnya, termasuk penggunaan media belajar 
dengan memanfaatkan media teknologi informasi dalam transfer of knowledges (transfer keilmuwan) dan transfer of values (transfer nilai-nilai).

Kemajuan dan perkembangan pesantren di Indonesia termasuk pesantren mahasiswa yang berada di sekitar kampus-kampus, tidak terlepas dari pengembangan software dan aplikasi studi Islam, khususnya bidang ilmu fiqh. Diantara perkembangan di bidang fiqh adalah e-book Al-Mausuat AlFiqhiyyyah Al-Kuwaitiyah. Bahkan perkembangan yang terbaru, e-book ini sudah bisa didowload di play store versi android. Sehingga sangat memudahkan para santri dalam mengaji dan mengembangkan pengetahuannya di bidang hukum Islam, dari berbagai aliran pemikiran hukum Islam.

\section{TINJAUAN PUSTAKA}

\subsection{Al-Mausuat Al-Fiqhiyyah}

Ebook Al-Mausuah Al-Fiqhiyah AlKuwatiyah/الموسوعة الفقهية الكويتية merupakan terobosan yang paling fenomenal di abad moderen ini. Karena ebook ini secara jujur membeberkan pemikiran dan pandangan hukum Islam secara komprehensif tanpa condong pada mainstream pemikiran Islam tertentu saja. Sehingga dengan membaca ebook ini para user tidak akan mendapatkan doktrin hukum Islam satu madzhab saja, melainkan seluruh madzhab fiqh/hukum Islam.

Problem masyarakat Islam saat ini, khususnya kalangan pesantren adalah minimnya sosialisasi dan pendalaman secara detil tentang manfaat, konten, dan penggunaan produk teknologi ini sebagai sumber belajar dan bahan ajar. Sehingga adanya penelitian tentang perbandingan madzhab hukum Islam pada ebook Al-Mausuah Al-Fiqhiyah AlKuwaitiyah/الموسوعة الفقهية الكويتية di salah satu pesantren menjadi sangat urgen. Dalam hal ini peneliti memilih Pesantren Mahasiswa Al-Fadhali Merjosari Malang sebagai objek penelitian, untuk menemukan efektifitas ebook sebagai bahan ajar dalam proses internalisasi nilai-nilai toleransi intraumat beragama.

Aplikasi Ebook (الموسوعة (الكويتية:Ensiklopedi Hukum Islam Kuwait) adalah salah satu aplikasi yang berisi kompilasi seluruh referensi hukum Islam dan kitab penunjang. Dalam aplikasi ini terdapat berbagai kitab ahlussunnah wal jama'ah yang sudah dikemas dalam bentuk ensiklopedi. Isi aplikasi ini memuat seluruh kitab klasik dari berbagai madzhab hukum Islam, khususnya madzab yang empat: Hanafiah, Malikiah, Syafi'iyah, dan Hanabilah. Bahkan di dalamnya terdapat madzhab pembanding, seperti pandanganpandangan Ibnu Taimiyah yang dalam pemikiran teologi dan hukum Islam sering berbeda dengan mayoritas umat Islam (KH. Sirajuddin Abbas, I'tiqad Ahlussunnah wal Jamaah).
Berbeda dengan software dan aplikasi yang diterbitkan oleh pemerintah Saudi Arabia pada umumnya mempunyai kecenderungan doktrinal dan sering menafikan pemikiran hukum Islam lain yang tidak sesuai dengan selera pemikiran madzhab hukum Islam di Saudi Arabia. Aplikasi Ebook (Ensiklopedi Hukum Islam Kuwait) didesain dan hadir lebih terbuka, demokratis, akomodatif, toleran, dan inklusif dengan seluruh pemikiran. Sejauh keputusan hukum itu masih berpedoman pada Al-Quran, sunnah, ijma', dan qiyas, maka diterima sabagai bagian dari hasil ijtihad. Tentu ada rajih (pendapat kuat) dan marjuh (lemah). Sehingga hadirnya aplikasi ini memberi pelajaran penting pada user dan pembaca millenial untuk menjelejahi seluruh pemikiran ulama empat madzhab dalam 1 aplikasi e-book. Dan bahkan sudah bisa dibaca dengan smartphone android.

\subsection{Nilai Plus Ebook Al-Mausuat}

Nilai-nilai plus yang tidak kalah pentingnya untuk diketahui halayak adalah

1. Ebook ini berbentuk ensiklopedia. Tidak ditulis dalam bentuk umumnya kitab-kitab fiqh yang didasarkan bab-bab hukum Islam seperti bab bersuci, bab shalat, dsb.

2. Semua istilah fiqh diterangkan dan diulas dengan sangat sempurna.

3. Ebook ini menampilkan orisinalitas isi kitabkitab klasik yang diakui secara jamak oleh ulama Islam internasional, mulai dari kitab-kitab yang ditulis sejak abad ke III Hijriyah sampai abad X Hijiriyah.

4. Berusaha memberi kesadaran pembaca agar tidak terjebak pada sikap eklusifisme berpikir, namun tetap pada jalur yang benar.

5. Aplikasi ini kitab aslinya (hardcopy) terdiri 45 jilid ini sudah disebarkan secara gratis oleh pemerintah Kuwait, baik dalam bentuk PDF, ebook versi desktop, dan smartphone android, sehingga sangat praktis belajar fiqh di mana dan kapan pun.

6. Setiap pembahasan dalam ebook ini dicantumkan referensi rujukan kitabnya.

7. Harakat/syakal redaksi ebook ini ditulis secara lengkap dan sulit ditemukan kesalah cetak tulisan huruf/harakat. Artinya sudah sangat instan.

\subsection{Gambaran Implementasi Ebook}

Pada bagian ini penulis akan sajikan gambaran contoh tampilan dari ebook Al-Mausuat AlFiqhiyah Al-Kuwaitiyah الموسوعة الفقهية الكويتية dalam bentuk desktop. 


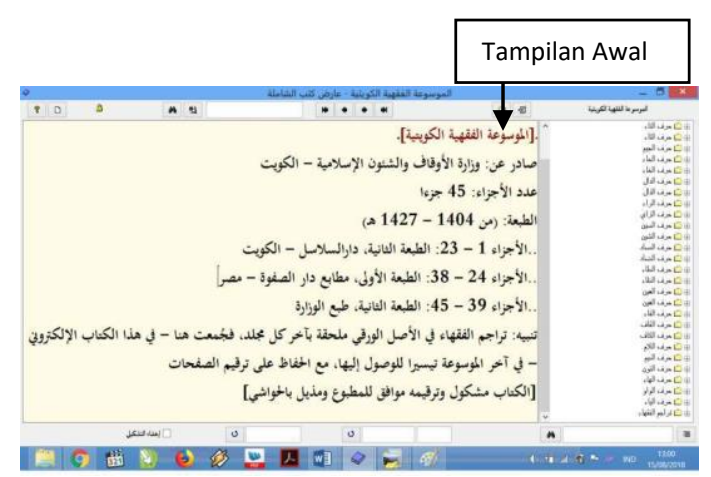

Gambar 1. Tampilan Ebook dalam format Desktop

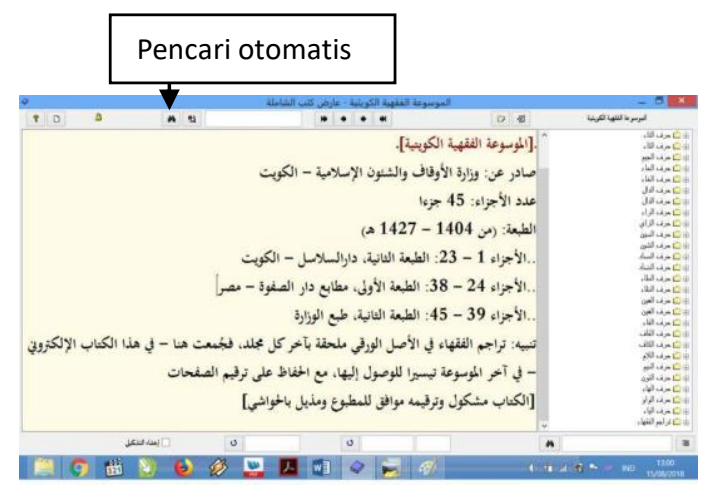

Gambar 2. Tampilan toolbar menu pencarian otomatis

Pada gambar 1 dan 2 terlihat tampilan awal dari ebook yang sangat sederhana, namun sudah lebih dari cukup untuk memudahkan user dalam mencari data hukum Islam. Sebagaimana pada gambar 2. Terdapat menu pencarian otomatis, yang sekali klik kata kunci, misal kata "قنوت", maka nanti mesin penelusur tersebut akan mengarah pada pembahasan yang terkait dengan hukum qunut; mulai dari makna qunut secara etimologi dan terminologi, hukum qunut shalat fajar, qunut nazilah, dan lain sebagainya.

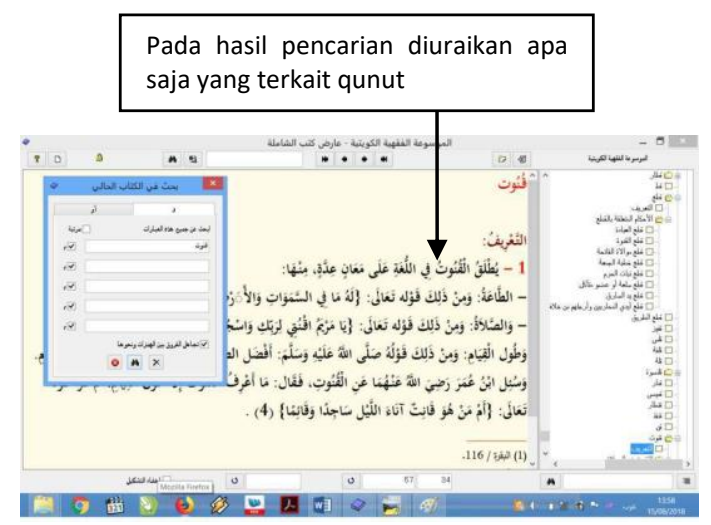

Gambar 3. Hasil pencarian tentang tema qunut

Menu pencarian di atas akan lebih efektif manakala digunakan oleh pembaca tingkat menengah ke atas. Yaitu mereka yang sudah menguasai bahasa Arab tentang hukum Islam. Khususnya para peneliti, dai, penulis lepas, atau para profesional yang mengajar di lembaga-lembaga pendidikan Islam di pesantren atau perguruan tinggi Islam.

Sedangkan untuk pembaca pemula, sebaikanya untuk membaca ebook ini secara manual. Karena akan lebih cepat menguasai subtansi pembasan secara mendalam, dengan mempelajari suatu tema pembahasan secara kronologis dan sistematis. Misalnya pembaca ingin mengetahui pembahasan "hukum qunut pada shalat shalat subuh," maka masuk entri huruf "ق." Berikutnya mencari akar kata "قتوت". Sebagaimana yang penulis simulasikan pada gambar berikut ini:

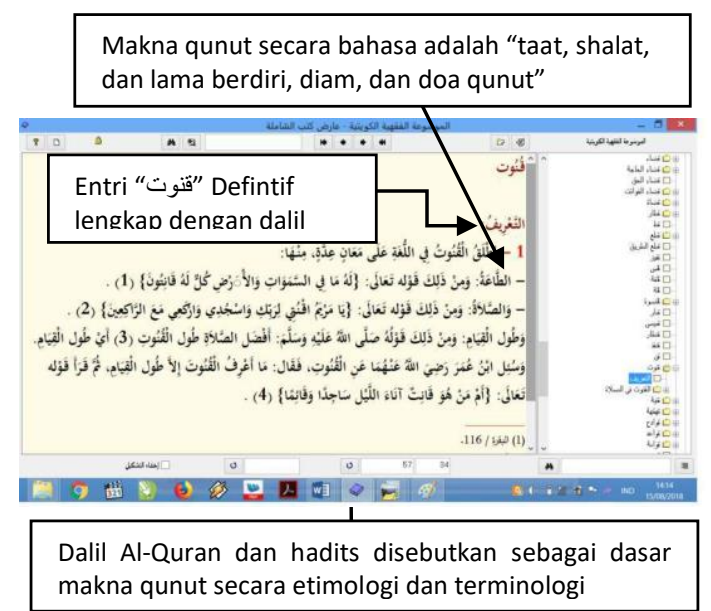

Gambar 4. Hasil pencarian manual tentang qunut secara bahasa Penjelasan tentang qunut secara istilah dan yang
masyhur di seluruh kitab figh menunjukkan arti doa
waktus shalat

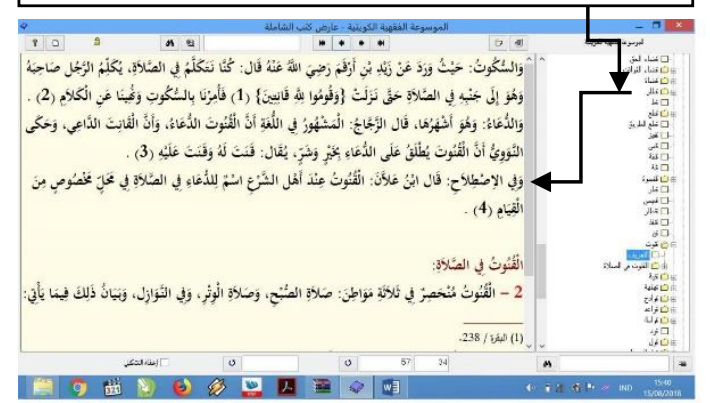

Gambar 5. Hasil pencarian manual tentang qunut secara bahasa dan istilah syariat.

Pada penjelasan menu gambar 5 ditegaskan bahwa qunut menurut ahli ilmu syariat adalah doa di dalam shalat, pada kondisi tertentu saat beridir di waktu shalat. Sebagaimana yang diterangkan kitab AL-Futuhat Ar-Rabbaniyah, syarah kitab Al-Adzkar An-Nawaiyah vol. II, hal. 286.

Dengan pembacaan manual sebagaimana gambar 4-5. di atas ebook ini bisa menjelaskan arti 
qunut secara bahasa dan istilah. Semua dalil yang tercantum di dalam Al-Quran dan hadits, serta interpretasi ulama fiqh disebutkan secara apadanya besarta referensinya. Para pembaca akan lebih terdidik untuk menerima perbedaan pemahaman sebagai keniscayaan, bila membaca penguraian ebook ini tentang perbedaan pandangan ulamaulama madzhab fiqh yang empat sebagaimana pada tampilan berikut:

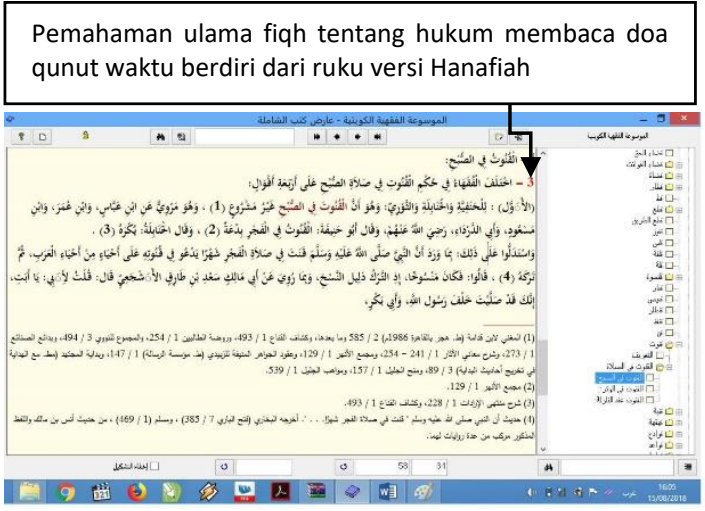

Gambar 6. Penguraian perbedaan hukum qunut

Berdasarkan gambar 6. di atas ebook AlMausuat ini memberi edukasi yang sangat berharga dengan internalisasi toleransi dan sikap inklusif pada pendapat-pendapat hukum Islam dari madzhab lain. Seperti pada contoh di atas dinyatakan oleh ulama Hanafiah bahwa membaca qunut pada waktu shalat subuh tidak disunnahkan, sebagaimana riwayat dari Ibnu Abbas, Ibnu Umar, Ibnu Mas'ud, dan Abu Darda'. Abu Hanifah berkat, membaca qunut di waktu shalat subuh adalah bid'ah, dan Al-Hanabilah berpendapat makruh.

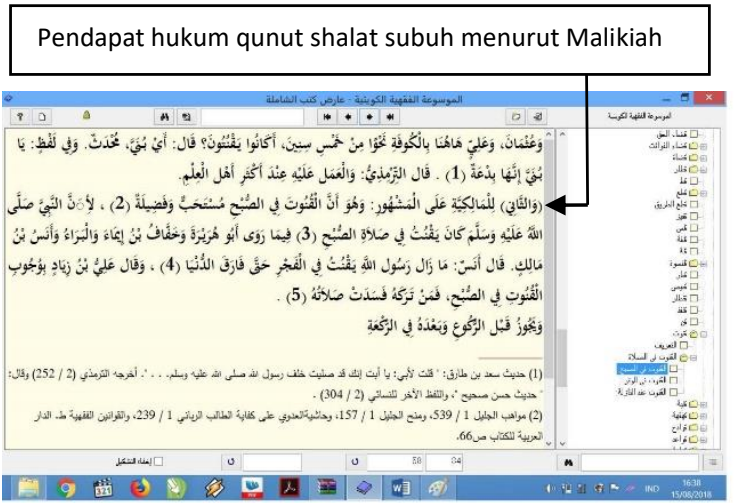

Gambar 7. Hukum qunut menurut Malikiah

Menurut ulama Malikiah, hukum qunut adalah mustahab dan keutamaan dalam shalat. Dengan dalil hadits riwayat Abu Hurairah dan Khafaf bin Ima'.

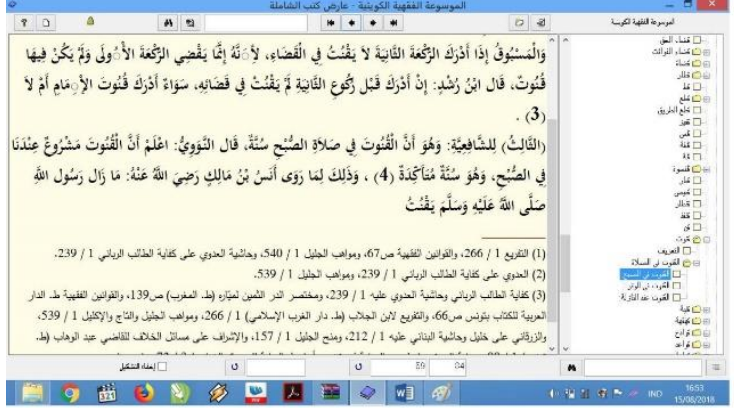

Gambar 8. Hukum qunut menurut Syafiiyah

Ulama syafi'iyah berpendapat bahwa qunut waktu shalat subuh hukumnya sunnah muakkadah (dianjurkan). Hukum ini didasarkan pada hadits Anas bin Malik, dan hadits Abu Hurairah yang dipedomani ulama Malaikiah. Al-Hasil, ebook AlMausuat Al-Fiqhiyah ini sangat efektif dan efesien untuk internalisasi nilai toleransi interaumat beragama, dan sangat eduktif dalam mendidik kesadaran untuk bersikap inklusif dengan pemikiran kelompok lain di bidang hukum Islam.

\subsection{Instal Ebook Al-Mausuat Al-Fiqhiyyah}

Seperti pada umunya aplikasi, ebook ini bisa diunduh gratis. Para pengguna bisa langsung masuk melalui link yang tertera di bawah ini:

1. http://shamela.ws/index.php/book/

2. http://www.shamela.ws/

atau bisa langsung ketik di chrome dengan kata kunci shamela books library maka akan muncul tampilan berikut ini:

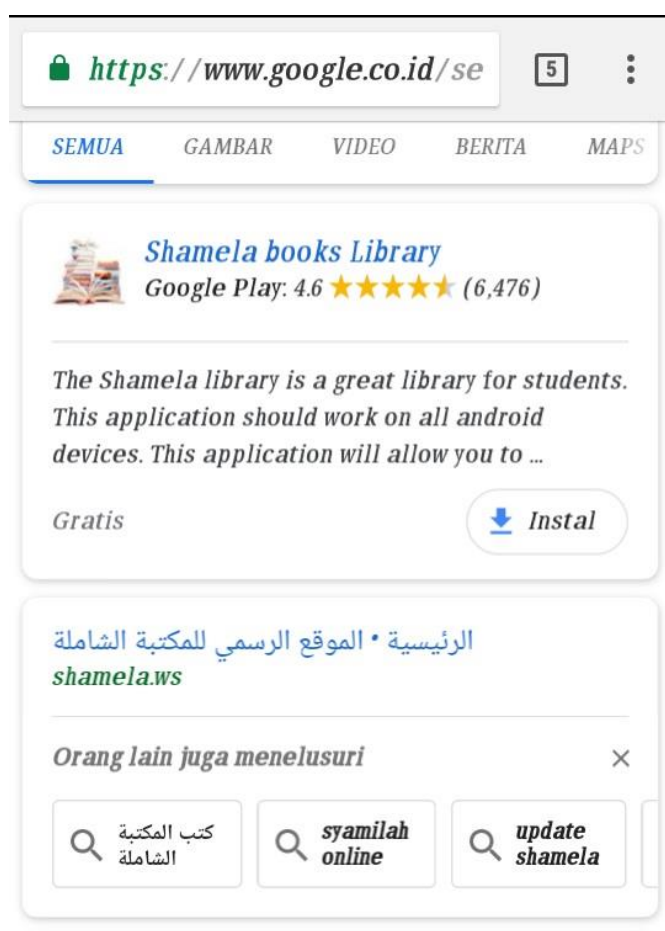

Gambar 9. Tampilan pencarian di google 
Pada gambar 9. di atas ebook Al-Mausuat bisa diunduh gratis. Lebih dari puluhan ribu judul bukubuku berbahasa Arab bisa didownload gratis, termasuk Al-Mausuat Al-Fiqhiyyah Al-Kuwaitiyah yang menjadi pembahasan artikel ini.

\section{METODE PENELITIAN}

\subsection{Metode dan Alat Penelitian}

Metode penelitian yang digunakan adalah dengan memberi pelatihan, penyuluhan, tes dan evaluasi. Pada tahapan berikutnya penulis melakukan wawancara dengan para santri di Pondok Pesantren Darul Ulum Al-Fadhali Merjosari Lowokwaru Malang. Adapun alat-alat penelitian yang digunakan dalam penelitian ini adalah:
1. Laptop
2. Mouse
3. Keyboard
4. Printer
5. Modul pelatihan
6. 7. LCD Projector
7. HP para santri, dan penulis

\subsection{Langkah-langkah Penelitian}

\section{Persiapan Penelitian}

Pada tahap persiapan penelitian ini, penulis melakukan pengamatan, survei pustaka, survei kurikulum pesantren mahasiswa Pondok Pesantren Darul Ulum Al-Fadhali, dan informasi tentang datadata terkait yang dibutuhkan untuk penemuan objektifitas hasil. Secara spesifik penulis melakukan wawancara terkait pemanfaatan media teknologi informasi sebagai sarana belajar dan mengajar.

\section{Perancangan Kebutuhan}

Pada tahap ini penulis melakukan identifikasi segala kebutuhan yang ada dengan mengelompokkan kebutuhan primer dan sekunder.

\section{Perancangan Pembuatan Soal-soal}

Penulis menyediakan soal-soal untuk menguji efektifitas ebook ini dalam internalisasi nilai toleransi interaumat beragama.

\section{Evaluasi dan Pengujian Pakar}

Dalam pengujian efektifitas ebook ini penulis bekerjasama dengan wakil pengasuh Pondok Pesantren Darul Al-Fadhali untuk memberi penilaian efektifitas internalisasi nilai-nilai toleransi interaumat beragama pada ebook Al-Mausuat AlFiqhiyah, apakah penggunaan ebook ini sudah bisa dinilai efektif untuk menanamkan nilai-nilai toleransi dalam perbedaan pemahaman hukum Islam?

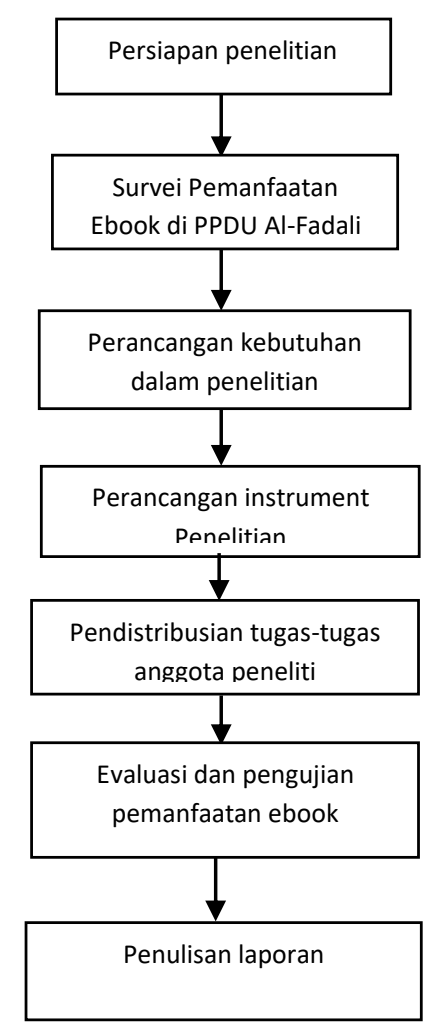

\subsection{Tujuan Penelitian}

Tujuan penelitian ini adalah untuk mengetahui efektifitas implementasi pemanfaatan media informasi dan komunikasi yang berupa ebook Al-Mausuat AlFiqhiyyah Al-Kuwaitiyah di Pondok Pesantren Darul Ulum Al-Fadhali Merjosari Lowokwaru Malang untuk internalisasi nilai-nilai toleransi dalam perbedaan pemahaman hukum Islam (fiqh). Mengingat mahalnya harga kitab-kitab fiqh yang berefek pada rendahnya minat baca kitab-kitab yang menguraikan khilafiyah, secara otomatis akan menanamkan sikap ekslusifisme pada pemahaman yang berada di luar buku kurikulum. Di sinilah peran ebook yang seluas Al-Mausuat Al-Fiqhiyyah menjadi sangat besar untuk internalisasi nilai-nilai toleran pada pemahaman keagamaan orang lain.

Terdapat tujuan lain yang sangat urgen yang ingin disumbangkan penulis kepada insan pesantren, pemerhati, dan masyarakat pendidikan Islam, terkait pemanfaatan media teknologi informasi sebagai media belajar ilmu agama dan dakwah Islam yang sanggup menanamkan nilai-nilai toleran di dunia pesantren. Sehingga pesantren bisa lebih adaptif dan komunikatif dengan perkembangan media teknologi informasi. Pada pencapaian yang ideal, seluruh aspek yang berhubungan dengan kurikulum, media dan metode pembelajaran, dan pengembangan keilmuan di pesantren dapat diintegrasikan dengan perkembangan dan lajunya teknologi informasi. 


\subsection{Manfaat Penelitian}

Penulis mempunyai harapan adanya manfaatmanfaat pada hasil penelitian sebagai berikut:

1. Memaksimalkan pemanfaatan teknologi informasi dan komunikasi sebagai media transfer ilmu agama di pesantren-pesantren tradisional yang berbasis digital.

2. Memberikan informasi efektifitas penguatan ilmu pengetahuan agama secara kognitif melalui kecanggihan teknologi informasi dan komunikasi.

3. Penyeimbang dan sekaligus benteng dari gencarnya serangan-serangan paham Islam transnasional yang juga berbasis teknologi informasi.

4. Memberikan wawasan pencerahan tentang generasi muda pesantren untuk kesiapannya dalam membendung arus-arus pemikiran Islam transnasional yang juga bisa berpotensi menjadi gerakan politik yang bisa memecah belah persatuan umat Islam Indonesia.

\section{HASIL DAN PEMBAHASAN}

\subsection{Internalisasi Nilai Toleransi}

Ebook Al-Mausuat Al-Fiqhiyyah AlKuwatiyyah/Ensiklopedia Hukum Islam Kuwait ini sangat mudah digunakan oleh seluruh kalangan. Mulai dari tingkat pemula, lanjutan, dan kelas peneliti studi Islam bisa mengaplikasikannya. Setiap pembaca yang mempunyai modal kemampuan membaca teks bahasa Arab, bisa dipastikan mampu menggunakan dan memanfaatkan ebook ini. Terlebih lagi bagi kalangan pesantren tradisional, bisa dipastikan mampu menggunakan ebook ini dengan sempurna.

Yang paling fenomenal dari ebook ini adalah, satu judul kitab fiqh, sudah bisa merangkum seluruh hukum Islam yang ditulis ulama mulai dari abad III$X$ hijriyah secara utuh dan komprehensif. Sebagaimana yang penulis uriaikan di atas, konten ebook ini sengaja didesain untuk menghapus fanatisme madzhab hukum Islam tertentu secara membabi buta. Karena semua pendapat hukum disajikan secara proporsional dan berimbang.

Pada ebook ini pembaca diberi kebebasan untuk memilih hukum Islam sesuai dengan kecenderungannya. Seluruh dalil masing-masing hukum ditampilkan tanpa adanya intervensi pertarjihan dari tim penyusun ensiklopedia ini. Dengan membaca ebook ini akan tertanam nilai keterbukaan dan kelapangan bahwa perbedaan pandangan hasil ijtihad hukum Islam sudah berjalan sejak masa Rasulullah SAW, sahabat, tabi'in, dst. Dari sinilah internalisasi nilai toleransi terbangun.

\subsection{Tabulasi Hasil Akhir Penelitian}

Setelah penulis melakukan wawancara dengan beberapa santri, ustadz, dan para user ebook ini, peneliti dapat menyimpulkan beberapa poin-poin penting terkait efektifitas internalisasi nilai-nilai toleransi interaumat beragama melalui belajar hukum Islam dengan ebook Al-Mausuat AlFiqhiyyah Al-Kuwaitiyah:

\begin{tabular}{|c|c|}
\hline 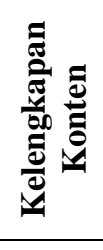 & $\begin{array}{l}\text { Semua pembahasan yang disajikan } \\
\text { sesuai dengan kitab-kitab yang dirujuk } \\
\text { dari seluruh madzhab fiqh yang empat: } \\
\text { Hanafiah, Malikiah, Syafi'iyah, dan } \\
\text { Hanabilah, plus Dzahariyah dan Ibnu } \\
\text { Taimiyah }\end{array}$ \\
\hline 苞 & $\begin{array}{l}\text { User/para santri dan para ustadz atau } \\
\text { ustadzah bisa menggunakan aplikasi } \\
\text { ebook ini dengan baik, karena bahasa } \\
\text { Arab yang disajikan di dalam } \\
\text { ensiklopedia sudah berharakat sempurna }\end{array}$ \\
\hline 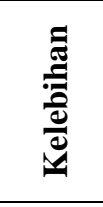 & $\begin{array}{l}\text { Ebook ini selain bisa digunakan dalam } \\
\text { format desktop, juga bisa dioperasikan } \\
\text { dengan smartphone android, baik yang } \\
\text { ram } 1 \text { gb atau } 2 \text { gb. Hanya kalau } 3 \text { giga } \\
\text { akan lebih cepat. }\end{array}$ \\
\hline
\end{tabular}

\section{KESIMPULAN DAN SARAN}

\subsection{Kesimpulan}

Ada beberapa kesimpulan penting untuk diketahui oleh khalayak umum, khususnya kalangan pesantren dan pengguna ebook Al-Mausuat AlFiqhiyyah Al-Kwaitiyyah sebagai berikut:

1. Pengembangan pembelajaran yang berbasiskan nilai-nilai universalitas Islam dapat dilakukan melalui media teknologi informasi yang sangat murah, efektif, dan efesien. Dengan demikian, pesantren sebagai jantung lembaga pendidikan Islam harus senantiasa meng-update perkembangan teknologi yang terkait penanaman nilai.

2. Penanaman nilai-nilai positif seperti toleransi, inklusif, dan kebinnekaan dapat dilakukan dengan bantuan teknologi informasi yang tepat guna. Sebagaiaman penggunaan smartphone untuk aplikasi buku keislaman, secara khusus ebook Al-Mausuat Al-Fiqhiyyah AlKuwaitiyyah.

3. Aplikasi Ebook ini merupakan pilihan santri millenial yang cerdas untuk pengembangan pemahaman perbedaan hukum Islam dengan buku gratis, yang harga hardcopynya mencapai 10 jutaan.

4. Penggunaan ebook ini sangat efektif dan efesien dalam transfer of knowledge dan transfer of value secara khusus untuk masyarakat pesantren. Terbukti di Pondok Pesantren Darul Ulum AlFadhali yang selama ini pembelajaran masih berbasis konvensional dan tradisional (тапиаl book), setelah diujicobakan pemanfaatan ebook pada smartphone masing-masing ustadz dan santri lebih mudah dan praktis untuk mengetahui sumber-sumber hukum. Sebagaimana implementasi tentang hukum membaca doa qunut di atas dapat diketahui bahwa antara yang 
qunut subuh dan tidak, semuanya berdasarkan dalil Al-Quran dan hadits.

Dengan demikian ebook Al-Mausuat AlFiqhiyyah Al-Kuwaitiyyah ini sangat cerdas dan efektif untuk internalisasi nilai-nilai toleransi akan perbedaan hukum Islam, khususnya dalam mengedukasi masyarakat pesantren agar tidak terjebak fanatisme sektarian yang membabi buta, yang selama ini sering meretakkan ukhuwah Islamiyah wathaniyah (persaudaraan Islam sesama anak bangsa) dan ukhuwah basyariyyah (persaudaraan sesama umat manusia).

\subsection{Saran}

Ada beberapa saran untuk pengelola, dan pengembang pendidikan Islam, khususnya pesantren untuk aktif dalam hal-hal berikut:

1. Menjadikan media belajar yang berbasis teknologi sebagai alat yang tepat guna dan sasaran
2. Membuka wawasan media teknologi informasi dan komunikasi sebagai alat pengajaran dan pendidikan

3. Mengembangkan media pembelajaran fiqh yang sesuai dengan kemajuan masyarakat millenial.

\section{DAFTAR PUSTAKA}

Munir, 2008. Pembelajaran Berbasis Teknologi Informasi dan Komunikasi. Bandung, Alfabeta.

Danim, Sudarwan. 2008. Media Komunikasi Pendidikan. Jakarta: PT. Bumi Aksara

Indriana, Dina. 2011. Ragam Alat Bantu Media Pengajaran. Jogjakarta: DIVA Press

Nasution, S. 2010. Teknologi Pendidikan. Jakarta: PT Bumi Aksara

http://lipi.go.id/berita/ebook-dan-pasar-perbukuankini/6669

http://www.mustanir.com/mengenal-al-mausuah-alfiqhiyyah-al-kuwaitiyyah/ 